\title{
EMPLOYMENT IN THE AGRARIAN SECTOR: DEMAND VS SUPPLY
}

\author{
P. L. Ivanova* \\ Department of Agricultural Economics, University of Economics - Varna, Varna, Bulgaria
}

\begin{abstract}
The topic about the differences between demand and supply in the labour market in all economic sectors becomes even more relevant. On the one hand, there are several active generations looking for employment and having different attitudes and expectations concerning a job; on the other, the differences in the qualification and experience required by employers and what applicants offer are getting bigger. The goal of this article is to reveal the new tendencies in the labour market in the agrarian sector. The following conclusions have been systematized: workers from the new generations look for challenging jobs with opportunities for career development; there is a deficit of experienced specialists and they are of key importance for achieving the business objectives of organizations; employers address to cooperation with both universities and vocational schools; an opportunity for increasing the quality of professional education is the dual system.
\end{abstract}

Key words: training, labour market, agricultural sector, employers

\section{INTRODUCTION}

Agriculture in Bulgaria is a significant factor for the economic and social development of the country; besides being beneficial for the society, it also contributes for providing employment in rural areas. Creating and maintaining employment in agriculture is a traditional objective of the General agrarian policy as well. In the last 50 years in Bulgaria and the countries of the European Union (EU) significant changes in the agrarian labour markets have been observed. They are influenced by the changes in agriculture, economy in rural areas and EU policies; there exists huge migration outside farms and one of the necessary conditions for growth and competitiveness of agriculture is the existence of a well-functioning labour market. This makes the topic about labour in the agrarian sector even more relevant.

Demand in the labour market in the agrarian sector is preconditioned by several active generations which have different attitudes and expectations in respect to employment; on the other hand, the differences in qualification and

*Correspondence to: Pavlina Lyubenova Ivanova, University Of Economics - Varna, Varna, Bulgaria, Department of Agricultural Economics, University of Economics - Varna, 77 Knyaz Boris I Blvd., 9002 Varna, Bulgaria, Phone: +359 882 164707, e-mail: p.ivanova@ue-varna.bg experience employers look for and what applicants offer are getting bigger.

The goal of this article is to reveal the new tendencies in the labour market in the agrarian sector, the discrepancies between demand and supply of labour, as well as the expectations of employers and workers.

To achieve the goal of the article there has been analyzed data of the National Statistical Institute (NSI), Employment Agency (EA), surveys of the Ministry of Labour and Social Policy (MLSP) and the European Centre for Development of Vocational Training (Cedefop).

\section{Employment in the agrarian sector}

There is no doubt about the social role of the agrarian sector in rural areas which face serious problems - depopulation, aging of population, high unemployment rate and poverty. Scientific literature discusses the issue of generating suitable job vacancies in rural areas as a result of growth in agriculture (1).

Successful development in the sector has a direct impact through increasing the income of farmers and indirectly through generating employment and decreasing prices of food. Higher incomes of farmers contribute for modernizing farms which presupposes the use of more qualified labour and higher salaries for workers. 
IVANOVA P. L.

The dynamics of employment in the agrarian sector in the period $2012-2016$, when after the crisis in all economic sectors there is a process of recovery and supply of new job vacancies, shows an increase of employees in the middle of the period: from 189,000 in 2012 to 208,900 people in 2014 and then a fall at the end of the period $-203,700$ in 2016 (2). The average number of the people employed in the last five years in the sector Agriculture, forestry and fishing has increased by 9.24 , growth in the public sector being $1.64 \%$ and in the public sector $-10.78 \%$. The relative share of those employed in the agrarian sector is $3.37 \%$ of all people employed in the country (Figure 1).

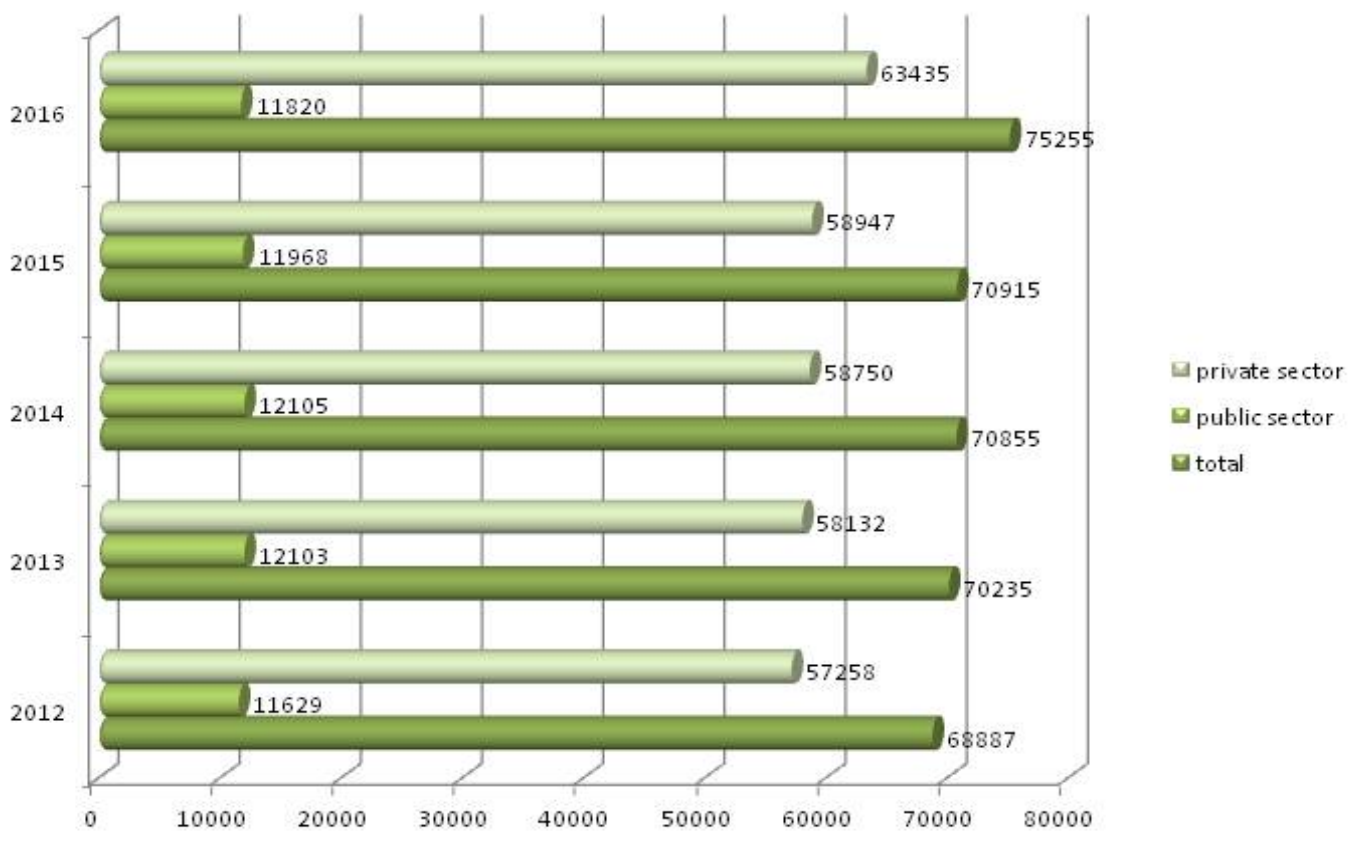

Figure 1. Average num ber of people with employment contract in the sector Agriculture, forestry and fishing in the period $2012-2016$

Source: NSI

The size of remuneration also rises - from mean annual salary BGN 7, 712 in 2012 to BGN 9,551 in 2016. The increase is 30\% (approximately the same as the increase of the mean annual salary in the country as a whole); salaries in the public sector being higher (Figure 2).

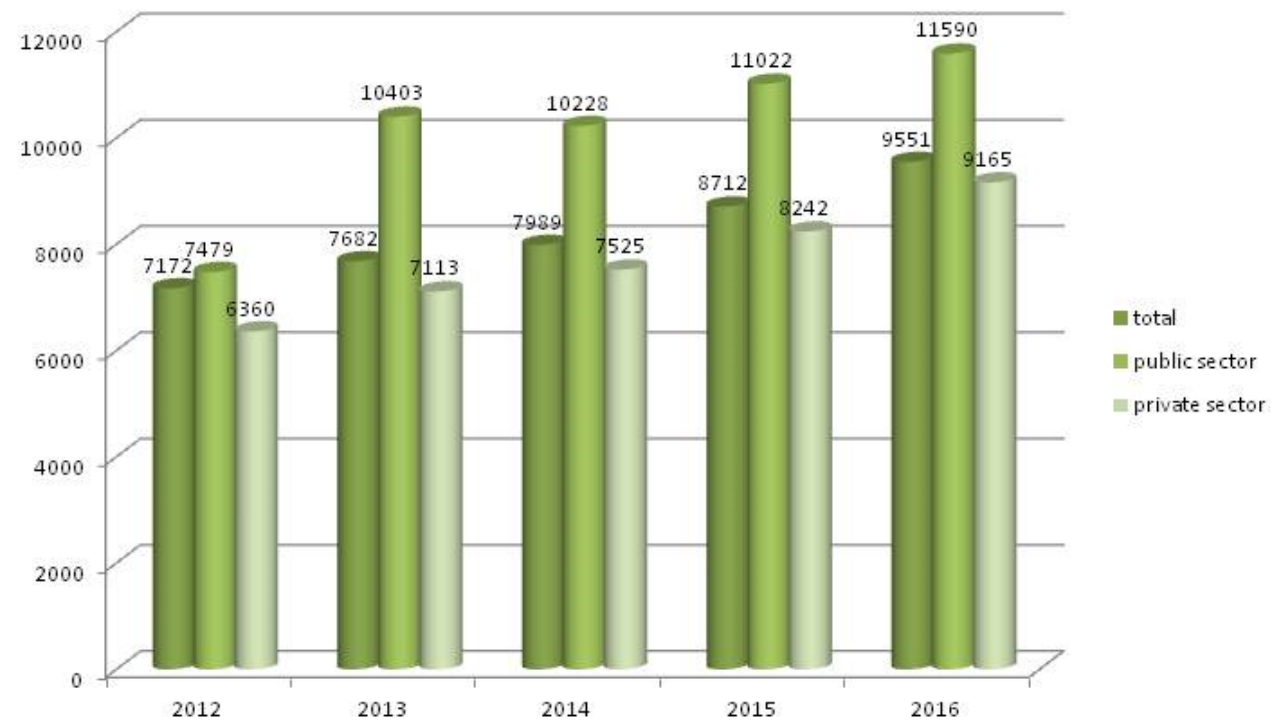

Figure 2. Mean annual salary in the sector Agriculture, forestryand fishing in the period $2012-2016$ 
During the period mentioned above, averagely $57 \%$ of the workforce in the sector is men. There prevail employees in the age range above 45 , the relative share of workers in the sector aged above 65 is significant $-25-28 \%$ average (3). In 2015 those employed in the sector Agriculture, forestry and fishing who have higher education are $8 \%$, employees with high education - 49\% and employees with secondary education $-43 \%$; their relative share in the remaining years of the period is approximately the same (4).

Especially characteristic of the sector is the division of employees in the categories family and non-family workforce. Traditionally high is the relative share of family workforce, these are people working in individuals' farms, members of their families. Permanently employed non-family workforce includes the workers who work regularly all year round or work regularly parts of the years depending of production conditions. Seasonal workforce is the workers hired by farms only for a certain period of time during an agricultural campaign.
The changes in labour legislation in 2015 regulated daily labour contracts, thus enabling farmers to employ many workers for a short time for the campaigns in planting. According to data of Industry Watch Bulgaria the number of people hired through a daily contract in the period July 2015 - September 2016 is above 23, 000 (5). A new opportunity for employers in the agrarian sector is offered also by the change in the Law of labour migration and labour mobility, made in 2017. Employers can hire seasonal workers from countries outside the European Union for a period of 90 days. This opportunity makes it easier for employers in the active season when demand for seasonal workers is the highest; yet, it creates for them more chores concerning the administration of foreign workers.

In the sector Agriculture, forestry and fishing $90 \%$ of the enterprises employ up to 9 workers, $8.5 \%$ employ 10-49 workers (Table 1). The enterprises with 0-49 employees provide approximately $70 \%$ of the employment in the sector (6).

Table 1. Number of enterprises in the sector Agriculture, forestry and fishing according to the number of people employed in the period $2012-2015$

\begin{tabular}{|l|l|l|l|l|}
\hline $\begin{array}{l}\text { Size according } \\
\text { to the number } \\
\text { of people } \\
\text { employed }\end{array}$ & $\begin{array}{l}\text { Number of } \\
\text { enterprises }\end{array}$ & $\begin{array}{l}\text { Number of } \\
\text { enterprises }\end{array}$ & $\begin{array}{l}\text { Number of } \\
\text { enterprises }\end{array}$ & $\begin{array}{l}\text { Number of } \\
\text { enterprises }\end{array}$ \\
\hline Total & 16221 & 17325 & 17583 & 19055 \\
\hline $\mathbf{0 - 9}$ & 14445 & 15544 & 15806 & 17276 \\
\hline $\mathbf{1 0}-\mathbf{4 9}$ & 1609 & 1600 & 1618 & 1625 \\
\hline $\mathbf{5 0}-\mathbf{2 4 9}$ & 154 & 169 & 146 & 142 \\
\hline $\mathbf{2 5 0}+$ & 13 & 12 & 13 & 12 \\
\hline
\end{tabular}

\section{Discrepancies in the demand and supply of labour in the agricultural sector}

Like every other market the labour one obeys the law of demand and supply. The behaviour of the participants in the labour market is various. Employers form the demand, while potential workers determine the supply in this market.

According to a national representative survey of EA among employers in various sectors, up to the middle of 2014 (7) the most important long-term factors influencing the Bulgarian labour market are the structural changes in the regional economies in respect to closing a number of leading productions for the respective regions; the discrepancies in the educational system, professional education and the characteristics of the workforce in demand; the uneven distribution of economic activity even within the same area; the weak labour mobility and unfair practices on behalf of employers.

Based on data from the above-mentioned survey of EA (7), the reasons for the discrepancies in the demand and supply of workforce in the agrarian sector boil down to the following:

- Existing mismatch on a regional level between employers' needs on the one hand and, on the other, the professional profile of specialists educated in the professional schools functioning on the territory of the separate regions. For this reason the young graduates with high professional education 
cannot find practical fulfillment in their specialty, while employers in the sector face permanent and great shortage of specialist with particular professional and qualification characteristics. Thus job openings are taken by individuals with unsuitable qualification which worsens the initial positions of start-up specialists and forces business to carry out training and requalification of the new employees.

In their study Foster and Rosenzweig (8) prove that increased supply of adequate education in rural areas later in time is linked to higher income for people and bigger entrepreneurship in the region.

An opportunity to provide qualified personnel is for companies to cooperate with universities, high schools and professional schools through trainee programmes. The effect for trainees is to feel the real business environment and to gather practical experience, the effect for business - to prepare personnel for its specific activities (9).

Most employers who took part in the study of EA (7) accept the introduction of dual education as a rational decision and a good variant for a way-out of the existing situation. As an example one can have Slovakia where pupils have a minimum of 1,400 hours of professional training monitored by a teacher in the professional school or a mentor in a company. The pupils who already work in companies are paid 50 to $100 \%$ of the remuneration for workers. Based on their employer's judgement, they are paid a monthly grant which could be four times bigger than the minimum life standard.

- The Bulgarian educational system lags behind the needs of the sector. Training is carried out under the guidance of curricula that do not comply with the reality in enterprises; the correlation between theoretical knowledge and practical preparation is not optimal; the material and technical base in schools is obsolete.

For example, the agricultural machinery in professional high schools does not match the modern and high-tech machinery which employers expect to be used later in time. New technologies require new competences as well, while employing qualified staff is of key importance for the efficient existence of organizations. Young and educated labour resources are the modern and thorough decision which can lead to economic growth and social well-being (10).
All this presupposes the complete change of the Bulgarian system of professional education by using good practices from other European countries. Antonova points out that the introduction of European examples in our system of professional education can lead to greater efficiency of education, quality and mobility of workforce and competitiveness of companies (11).

- Young people have clearly expressed preferences to modern and attractive professions with prestigious titles. The professional orientation and the attitudes for doing a type of job are formed within the family. A large number of parents encourage their children to apply for specialties with prestigious names which provide opportunities for career development in "prestigious" or "modern" professions. In practice the family turns out to be one of the leading factors for shifting social interest in the so-called modern or prestigious specialties and professions.

This necessitates changing the image of the branch itself, the professions in it and the way society accepts them. The social significance of these professions still lacks the level for creating the necessary image of a serious and significant professional vision of those who work in the branch (12).

- Young people do not have clearly expressed motivation for professional development. Instead, they are interested in opportunities for career advancement (taking particular positions) and receiving higher remuneration for labour (7). What they lack is strive for acquiring practical skills and for professional development in the branch.

- Working pensioners and their impact on the demand and supply of workforce. Opinions on this issue vary to extremes since, on the one hand, because of low pensions retired people are forced to work which is an objective

impediment to the fulfillment of young people. On the other hand, pensioners have the experience young people lack.

- Unrealistic expectations of employers and applicants concerning a job. It is common for job applicants to have exceptionally high requirements and demand unjustifiably high remuneration or be interested only in how much they will be paid instead of showing interest in work duties and real work they will be assigned. Applicants turn in without any experience and expect to be appointed at highly-paid positions. Employers, in turn, also have unrealistic requirements. Usually these refer to previous experience which contradicts other requirements, for 
example for applicants to be young and be able to speak several languages.

- The lack of coordination and cohesion in the activities of institutions which concern the labour market and execute particular functions in relation to education, qualification, requalification and fulfillment of people. Often there is a lack of coordination in activities and consistency between separate institutions.

\section{Work in the agricultural sector - tendencies and expectations}

In the sector of Agriculture, forestry and fishing one observes shortage of qualified specialists - there are not enough individuals able to work with modern agricultural machinery, as well as lowly qualified workers to do less mechanized work. More modern farms which have implemented overall decisions for production management with precise systems for navigation, reporting various indicators in plant and animal breeding; farms, which use modern agricultural machinery and specialized software in their administrative work, look for people with training to work with new technologies (13).

The mean number of announced job openings in the sector in the period 2012 - 2016 varies between 340 and 623 , the number being the highest in 2016 (Figure 3). According to forecasts of Cedefop (14) on the demand and supply of labour, in sectors in the period 2015 - 2025 a decrease in employment is expected in the sector Agriculture, forestry and fishing. They predict also negative growth (-14.9\%) particularly for the professions in the category "Qualified production workers in agriculture".

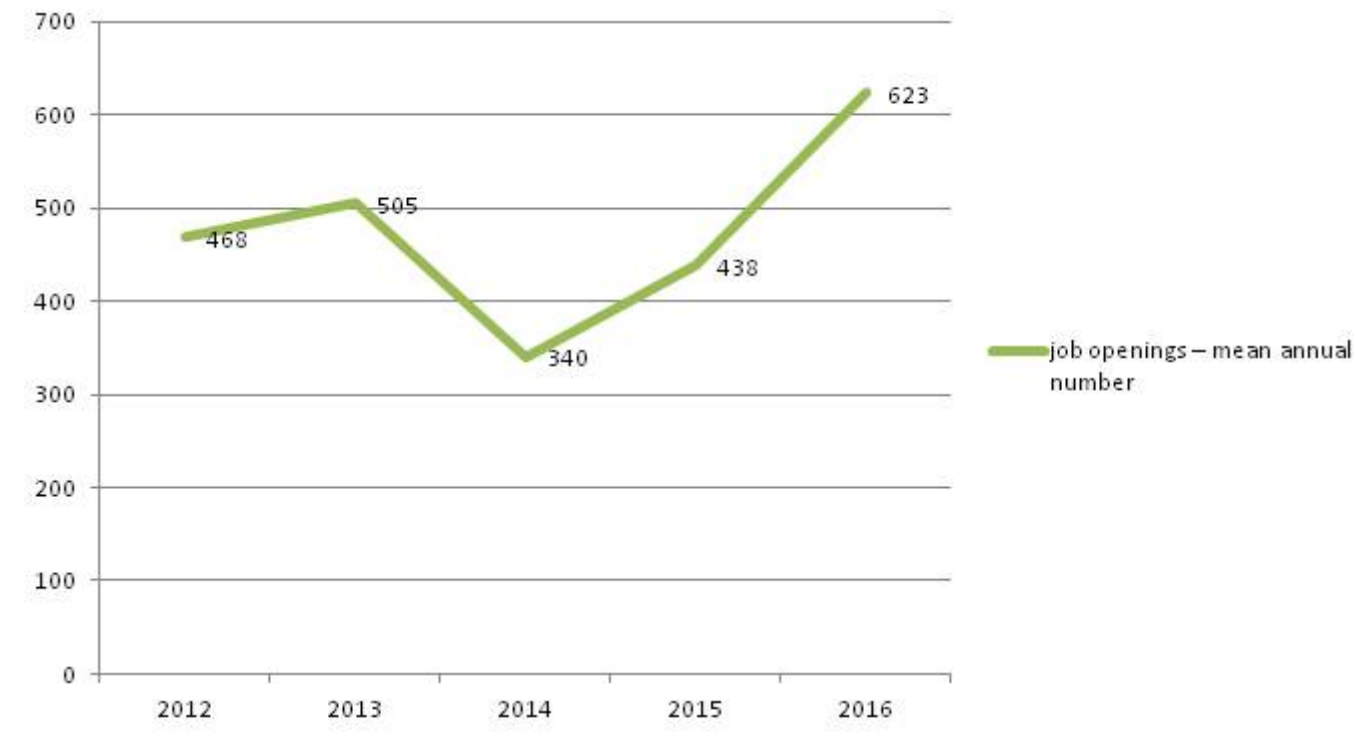

Figure 3. Mean annual number of announced job opening in the sector Agriculture, forestryand fishing in

the period $2012-2016$

Source: $N S I$

The distribution of job openings according to categories of professions is one of the key indicators showing the demand and supply of labour concerning individuals with particular qualification. In the agrarian sector there is demand for professions from all categories: managers and leading specialists, accountants and commercial representatives, agronomist and veterinary doctors, qualified agricultural workers and operators of agrarian machinery, crop raisers and stock breeders and others.
In the survey of EA (7) employers in the agrarian sector point out that professional experience is of great importance when hiring new workers; new and especially small companies, which are in great need of workforce but are not sure whether they will survive and how long they will be active in the market, need well-prepared and established specialists who can join the company and start work immediately. Firms with more than 5 years working history, which believe they will be successful in the future and the big companies, which are sure in their markets and thus feel confident when looking for new staff, have a different policy for managing human resources, it is based on their stable business 
IVANOVA P. L.

plans - they have a clear idea of the type of specialists and respectively professions they need now and in 5-10 years, they have plans for possible enlargement of production and so on. Moreover: quite a few of this type of enterprises accept pupils and students for internship, thus they themselves take part in preparing the staff they need.

\section{CONCLUSION}

Based on everything stated so far one can sum up that:

Each regional economy needs to have a clear vision about what economic activities and which branches will be developed and thus create professional schools with profile that is adequate to its branch structure.

The companies in the branch have to work for changing the image of the professions in the sector and thus meet the expectations of workers from the new generations who look for challenging jobs with opportunities for career development.

It is possible to overcome the existing deficit of well-prepared specialists through cooperation of employers and both universities and professional schools. Another opportunity for increasing the quality of professional education is to implement the dual system.

\section{REFERENCES}

1. Foster,A.D., Creating Good Employment Opportunities for the Rural Sector. ADB Economics Working Paper Series, 271, Philippines, 2011.

2. Agricultural Report 2012, 2013, 2014, 2015, 2016. [Online]. Available at: http://www.mzh.government.bg/mzh/Docu ments/reports.aspx [Accessed 10.06.2017].

3. Structure_agricultural_holdings 2012, 2013, 2014, 2015. [Online]. Available at: http://www.mzh.government.bg/MZH/Shor tLinks/SelskaPolitika/Agrostatistics/Structu re_agricultural_holdings/Results.aspx [Accessed 10.06.2017].

4. Demand and Supply of Labor in Bulgaria 2015 - 2016. Estimates of Labor Market Developments by 2025. Ministry of Labour and Social Policy. [Online]. Available at: https://www.mlsp.government.bg/index.php ?section=POLICIESI $\&$ lang $=\& \mathrm{I}=246$

[Accessed 10.06.2017].
5. Economic Effects of One-day Employment Contracts. Industry Watch Bulgaria. [Online]. Available at: http://www.iwatchbulgaria.com [Accessed 10.06.2017].

6. National Statistical Institute. Business Statistics. [Online]. Available at: http://www.nsi.bg/en/content/13209/annual -business-statisticsx [Accessed 10.06.2017].

7. Analysis of the situation of enterprises in Bulgaria with respect to the development of human resources. Short-term prospects for the development of the labor market in Bulgaria. Ministry of Labour and Social Policy. [Online]. Available at: https://www.mlsp.government.bg/index.php ?section $=$ POLICIESI\&lang $=\& \mathrm{I}=246$ [Accessed 10.06.2017].

8. Foster, A. D., Rosenzweig. M. R. Agricultural Development, Industrialization and Rural Inequality. Department of Economics, Brown University, 2005.

9. Shishmanov, K., Shishmanova, P., The role of the business in raising the quality of human capital in Bulgaria. Scientific Research Almanac. Svishtov, 2010.

10.Istudor, N., et al, Educational needs in the field of agriculture and rural development in the Lower Danube region. Business management 5(3), pp. 71-89, 2011.

11.Antonova, K., Policies and Practices in Vocational Training in Bulgaria and the European Union - Comparative Characteristics. Izvestiya Journal. 3. pp.150-163, 2009.

12.Jeliazkov, A., et al. Sectoral Analysis of Labor Force Competencies in the Production of Milk and Milk Products. [Online]. Available at: http://www.milkbg.org/language/bg/upload s/files/documents [Accessed 10.05.2017].

13.Ivanova, P. Challenges for Employers in the Agrarian Sector. Proceedings of the VIII International Scientific Conference The Economy In The Change World National, Regional and Global Dimensions. Varna, Bulgaria. pp. 77-83, 2017.

14.European Center for the Development of Vocational Training (Cedefop). A project for the demand and supply of qualifications and skills by 2025. [Online]. Available at: http://www.cedefop.europa.eu/en/eventsand-projects/projects/forecasting-skilldemand-and-supply 